Article

\title{
Monitoring and Evaluation Framework for Spatial Plans: A Spanish Case Study
}

\author{
Sergio Segura and Belen Pedregal * \\ Department of Human Geography, Universidad de Sevilla, Calle San Fernando, 4, 41004 Sevilla, Spain; \\ ssegura@us.es \\ * Correspondence: bpedregal@us.es; Tel.: +34-954-551-466
}

Received: 27 July 2017; Accepted: 20 September 2017; Published: 23 September 2017

\begin{abstract}
Spatial planning, as a regional and subregional public policy, establishes a territorial integral vision implemented through spatial plans, aimed at achieving a balanced and sustainable spatial development and improving quality of life. To enhance the effectiveness of these plans, evaluation and monitoring are needed. This paper critically analyses the monitoring and evaluation framework for spatial plans in Spain. Based on extensive literature, legislative, and document review, as well as in-depth interviews with key stakeholders, the paper describes the legal provisions of spatial plans and how they work in practice. One of the main conclusions is that, although many laws and spatial plans have been adopted in Spain, they do not include sufficient details and provisions regarding basic monitoring and evaluation procedures. This practice is in fact highly dependent on the political will of regional governments. The main progress on monitoring and evaluation of spatial plans is achieved thanks to the enforcement of environmental legislation. Finally, it is suggested that the role of specific bodies, public participation, territorial observatories, and indicator systems should be strengthened as key elements of the evaluation and monitoring procedures for spatial planning.
\end{abstract}

Keywords: monitoring framework; spatial planning; evaluation; territorial observatories; SEA Directive; Spanish legislative frame

\section{Introduction}

Since the Torremolinos Charter 1983 (adopted in 1983 by the Council of Europe Conference of Ministers Responsible for Spatial/Regional Planning (CEMAT)), spatial planning in Europe has been understood as a long-term policy which sets a territorial comprehensive vision directed towards a balanced regional development and the physical organisation of space according to an overall strategy. The Charter's principles established the essential aim of sustainable development for spatial planning [1] (p. 2): (i) balanced socioeconomic development of the regions; (ii) improvement of the quality of life; (iii) responsible management of natural resources and protection of the environment; and (iv) rational use of land.

For this purpose, spatial planning includes decision processes about structural spatial elements, such as networks of settlements, infrastructure, and services, as well as natural and cultural resources and heritage. In spatial planning, regional and subregional scales are important, as these are the scales chosen in most countries for spatial planning, whereas urban planning is restricted to the local scale [2].

In the European context, a number of steps have been taken to support planning in member countries. In 1999, the European Spatial Development Perspective (ESDP) was signed by the ministers responsible for regional planning in the EU member states. Although the ESDP has no binding status, as the European Union has no formal authority for spatial planning, the ESDP has influenced spatial planning policy in European regions and member states [3].

The European Green Paper on Territorial Cohesion expanded the aim of spatial planning towards achieving a more balanced and harmonious territorial development. In this regard, it is understood 
that planning and management are important instruments for transforming territorial diversity into an asset that contributes to sustainable development [4]. Therefore, there are high demands and expectations on spatial planning to support society with physical structures that make it possible for people to act and live in a more sustainable way [3].

In the last few years, spatial planning has also been understood as the process of decision making on the use of land in a society, based on assessing and balancing competing demands. Consequently, it is directly related to governance discourse [5]. An increasing complexity characterises spatial planning policy, not only as a consequence of the diversity of procedures both between and within countries [6,7], but also as a result of the number of territorial actors that take part in spatial planning decision processes. Territorial stakeholders include those individuals and collectives that use territorial resources and perceive themselves as affected by spatial planning decision making. An additional level of complexity arises from overlapping of other public policies with a spatial impact [8]. Usually, all of these interactions bring up conflicts. Furthermore, no single international paradigm exists that can be used as a theoretical model for spatial planning, as both spatial planning orientations and social needs are in constant evolution [6].

Spatial planning is implemented mainly through spatial plans but also is affected by other sectoral policies. In Spain, spatial plans are statutory documents that establish general and specific territorial guidelines at different scales for operational and spatial restructuring purposes [9] (pp. 483-484). These plans have a common structure based on alignment with pre-established objectives, a timeline for actions to be implemented, and expected results. Spatial plans are generally based on a territorial diagnosis and an analysis of trends of the territorial dynamics, aimed at identifying constraints and potential benefits derived from territorial projects. Other sectoral statutory documents, such as environmental or water management and risk legislation, establish general and specific guidelines and techniques affecting spatial planning at different scales for operational and spatial restructuring purposes.

Furthermore, spatial planning is a continuous process. In that sense, evaluation, monitoring, and review of spatial plans are essential to promote the continuing effectiveness of spatial planning [10,11]. However, there is general agreement among specialists that the measurement of the effectiveness and outcomes of planning is a challenging task due to the complexity involved in spatial planning activities and the limitation of any single method as a means of effectively measuring the outcome and impact of these activities [12].

There are important contributions in the international literature that point out the difficulties involved in evaluating spatial planning outcomes. Various authors highlight the difficulty of isolating the impacts of spatial planning from other public policies, as well as the scarcity of reliable data available [12]. Many of these studies have focused on contributing to the development of better indicators for the assessment of policy impacts on the key objectives, mainly at local scales [6-8,13-19]. There are fewer analyses, however, of the monitoring system itself, the legal provisions for monitoring in spatial planning, how they are really working on the ground, and whether they are meeting their objectives.

This paper aims to contribute to this area by critically analysing the monitoring and evaluation framework of spatial plans in Spain. Based on extensive literature, legislative, and document review, as well as in-depth interviews with key stakeholders, the paper describes the legal provisions of spatial plans and how they work in reality. By doing so, main barriers and setbacks are identified and some recommendations provided that could contribute to enhance this practice internationally.

The paper is organised into six sections. Following this introduction, the second section discusses the concept of evaluation and monitoring framework as applied in this study. The third section lays out the institutional context of spatial planning in Spain. The fourth section outlines the methodological approach used to conduct this work. The fifth section discusses the effectiveness of the Spanish spatial planning legislation provisions for evaluating and monitoring of plans. The final section presents some concluding remarks and recommendations. 


\section{Conceptualising Evaluation and Monitoring Framework}

In this paper, spatial plan evaluation refers to the processes needed to measure the achievement of the objectives and established goals and to suggest proper policy and design changes [20]. To carry out an evaluation, we must identify tools to measure the performance of the actions and policies, and to solve problems related to implementation and effectiveness of policies [21]. Spatial plan evaluations are needed to promote a smart spatial approach, defined as a means for researchers, stakeholders, and the local community to acquire better knowledge of the territory to better manage its development $[22,23]$. Evaluation can be carried out at any time of the planning process and, unlike monitoring, it can be performed by external agents that are not part of the team in charge of the plan (See Table 1). Usually, the evaluation of objectives is performed with the aid of indicators, which are considered a fundamental element for the evaluation of spatial policies since the 1970s U.S. National Environmental Policy Act [24-26].

On the other hand, in this paper, spatial plan monitoring refers to a set of regulated processes that continuously and systematically gather information on a plan during the execution period. This monitoring should be used in order to control and report contingencies or possible correction of the plan (See Table 1).

Table 1. Differences between evaluation and monitoring of the spatial plans.

\begin{tabular}{cll}
\hline \multicolumn{1}{c}{ Aspects } & \multicolumn{1}{c}{ Evaluation } & \multicolumn{1}{c}{ Monitoring } \\
\hline Purpose & $\begin{array}{l}\text { Accountability, information, improvement of } \\
\text { the design and implementation of the plan }\end{array}$ & $\begin{array}{l}\text { To ensure that what is planned and } \\
\text { regulated is actually enforced }\end{array}$ \\
\hline When it is performed & $\begin{array}{l}\text { Before, during, and after implementation of } \\
\text { the plan }\end{array}$ & During implementation of the plan \\
\hline Who performs it & External or internal evaluators & Team in charge of the plan \\
\hline Content of the process & $\begin{array}{l}\text { Assess relevance, usefulness, effectiveness } \\
\text { and efficiency }\end{array}$ & Measure the performance and results \\
\hline Aim of the process & Assess the adequacy of the plan & Correct deviations \\
\hline Notion of public action & Allows questioning the plan & Does not question the plan \\
\hline & Source: Adapted based on Benabent, 2014 [27] (p. 130).
\end{tabular}

Based on the previous definitions, for the purposes of this paper, monitoring and evaluation framework for spatial plans refers to all bodies, instruments, and processes established and regulated by legislation to promote an effective feedback on spatial plans.

\section{Spatial Planning in Spain}

The origins of spatial planning in Spain go back to the metropolitan urban plans of the beginning of the 20th century. After the transition to democracy and the Spanish Constitution of 1978, it acquired a relevant role. Since devolution of responsibilities to the regions up to the end of the 20th century, several national authors have published on the field of spatial planning, both from a theoretical and practical point of view. Several publications from the beginning of the 21st century are deemed essential in the field and describe spatial planning in Spain as a main challenge [28-40].

Very little literature exists, however, on the evaluation of implementation of spatial planning policy in Spain. There is much more academic literature about environmental assessment of spatial plans. Environmental issues have long been considered—and rightly so-as fundamental in spatial and urban planning [41-44]. Therefore, it is understandable that the environmental assessment has a longer tradition than the evaluation and monitoring programs of the Spanish spatial plans, although they have many points in common. According to most authors, these points in common should be strengthened and procedures should be integrated [44]. 
Spatial planning was established in article 148.1 of the Spanish Constitution as an exclusive competence of Spanish regions, similar to competences on urban planning and housing, which are closely related. Since then regional spatial planning legislation was passed that differentiated it from urban planning and provided it with its own specific planning instruments [33], these laws and plans have become a general practice, notwithstanding the political ideology of the different Spanish regional governments. Consequently, many urban metropolitan and coastal areas' spatial plans were approved [39]. However, several sectoral and cross-sectoral responsibilities still lie with central government, such as specific infrastructure policies that, along with economic planning, have a direct impact on spatial planning.

Furthermore, we emphasize that in Spain there is a low awareness of spatial planning issues. Ten years ago the Professional Society of Geographers and the Association of Spanish Geographers (AGE) tabled a manifesto for a new territorial culture in 2006 [45]. The manifesto was initially signed by 108 experts and intended to halt the unlimited urban development that has dominated Spain, and especially its coasts, in the past several decades [46]. Despite the manifesto, civil society and planners themselves have not actively heeded its call, and urban development has been slowed primarily by the economic crisis at the beginning of this decade.

The different regional legislations all define a similar spatial planning system with similar intervention tools, which have followed very different paths. They are based on two fundamental scales: regional spatial plans and subregional spatial plans [40]. In some regions, the regional spatial plan is merely a strategic spatial framework. Generally, although not in all cases, these regional spatial plans establish guidelines, laws, or recommendations on land use. With a few exceptions, subregional spatial plans are more specific than the regional plans. They are related to intermediate territorial scales between regional and local planning (in Spain this would be the scale of provinces, counties, or supra-municipal level).

Figure 1 shows the final approval year of all the laws that make up the main legal framework on regional spatial planning in Spain. The first law was approved in Catalonia in 1983 and the last one was in 2015. None of these regional laws have any national legislation that serves as a reference framework. As a result, there is a lack of coherence and consensus to develop and implement spatial plans in Spain [40]. In some cases, regional, national, and international sectoral legislation affect spatial plans. For example, this is the case with European environmental legislation, legislation on landscape in Catalonia, coastal area regulations in Andalusia, and legislation of land classification schemes in Murcia. Many different changes and modifications of original spatial planning laws have been passed, although some of them are still in force with few changes, as is the case in Andalusia and Catalonia.

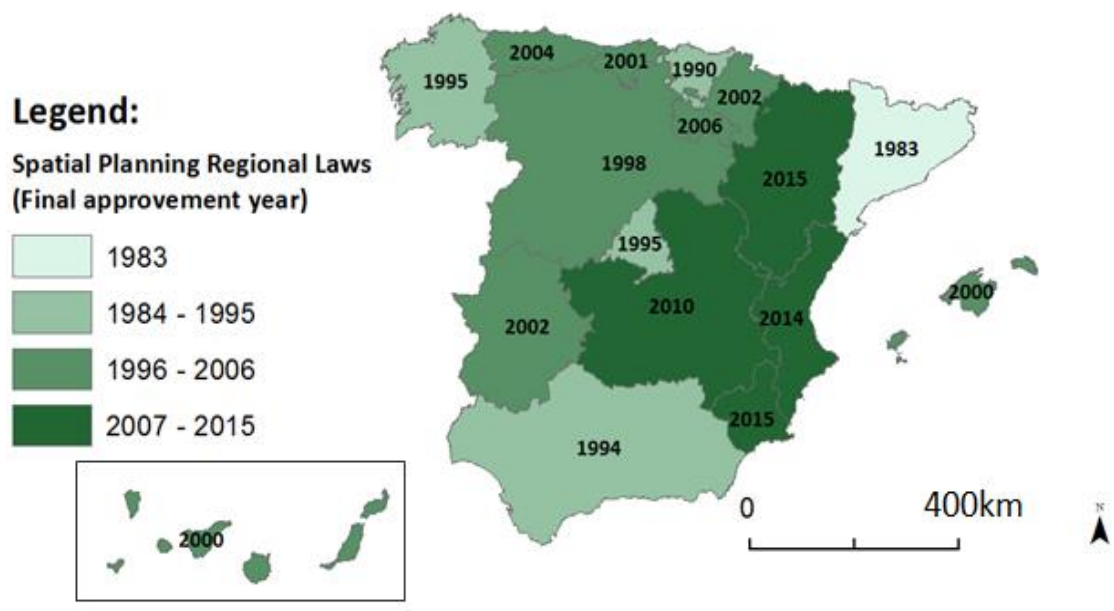

Figure 1. Final approval year of Regional Laws on Spatial Planning in force in Spain. (Source: Own preparation based on regional Spanish spatial planning laws.) 
One of the main features of Spanish regional spatial planning laws is that they are instrumental, which means that spatial plans establish legally binding norms [34]. Consequently, spatial plans in Spain have a double nature: on the one hand, they promote spatial transformations in order to achieve sustainable territorial development; and, on the other hand, they regulate and restrict certain activities and land uses [29]. However, Spanish spatial plans are primarily strategic rather than regulatory, especially on the regional scale.

As we have previously mentioned, Spanish spatial plans have two basic scales: the regional and subregional; whereas urban planning is restricted to the local scale. Both types of plans have been approved in the form of legal decrees that provide for regulations and recommendations, although in the past few years legislation has become more flexible and proactive rather than regulatory [39]. This is consistent with the latest European and Spanish planning theory. Spatial planning processes focus on the territorial agreement between stakeholders rather than hard regulatory spatial plans. This focus aims to resolve the complexity of multilevel spatial planning and related stakeholder involvement processes $[8,22,47-50]$.

In some cases, more than a decade has elapsed between the regional law and the approval of the regional spatial plan. Until 2016 only the regions of Madrid and Murcia had not approved the regional spatial plan. It is common knowledge that subregional spatial plans have proliferated since the beginning of this century. According to many experts, there is a need to complement the regional spatial plan with more legally binding subregional plans in order to guarantee the enforcement of spatial planning guidelines [51]. This range of levels of legally binding commitment implies that regional spatial plans are more general in nature, whereas subregional plans define more specific legal arrangements, applying the principle of subsidiarity [30]. Catalonia, Navarra, Basque Country, Andalusia, Canary Islands, and Balearic Islands have all approved regional and subregional plans. On the other hand, Extremadura and the region of Valencia have not approved any subregional spatial plan and they are currently processing the draft proposals of their first subregional spatial planning instruments.

\section{Methodology}

To analyse the evaluation and monitoring frameworks for spatial planning, we examined the legislation in force in each of the 17 Spanish regions (equivalent to NUTS 2 in the Classification of Territorial Units for Statistics of the European Union). Once all provisions for the evaluation and monitoring of spatial plans were identified, we performed a critical analysis of their actual situation based on the review of scientific literature and interviews with key stakeholders. We conducted the interviews within the framework of the GOBEFTER project (GOBEFTER: From government to governance and effective territorial governability; Guidelines for a new spatial development, supported by the Ministry of Economy, Industry and Competitiveness (MIMECO) under grant GOBEFTER, Ref. CS02012-36960). Two specific case studies were selected: Andalusia-the region with the most spatial plans in Spain - and the Valencia region, which was in the process of developing its regional spatial strategy during this research.

Interviews consisted of a structured conversation based on open questions using the snowball method. This is a non-probability sampling technique based on chain sampling that is ideal to identify the most interesting actors in this type of study. The main contacts were provided by relevant experts that were also being interviewed. This is one of the most appropriate and widely used methods in the field of social science [52].

For each case study, four interviews of approximately one hour were performed with relevant spatial planning experts with a technical, political, professional, and/or academic profile (Table 2). Whenever possible, a second round of interviews was held in order to fill in necessary information. Interviews were held between 2014 and 2016. The interviews were established as anonymous to ensure a high level of candour. The academic and policy-making profiles were most prevalent in the interviews, although all profiles were considered in order to complete the analysis. 
Table 2. Profile of interviewees.

\begin{tabular}{ccc}
\hline Profile of Interviewees & Andalusia & Valencia \\
\hline Technical staff (public administration) & 1 & 3 \\
Professionals & 1 & 1 \\
Academics & 3 & 2 \\
Policy makers & 3 & 1 \\
\hline
\end{tabular}

Note: A total of eight interviews were performed, four for each case study. Most interviewees fit into two or more profile categories. Source: Own preparation.

The structured interview template (Appendix A) served as a basis to obtain the necessary information to meet the objectives of this research. The questionnaire consisted of ten open questions aimed at exploring the current status of evaluation, monitoring, and renewal of spatial plans according to law. Questions referred to the existing monitoring reports, the tasks of the evaluation and monitoring commissions, the role of public participation, the functionality and activities of the territorial observatories, and spatial information and indicators. Special attention was also paid to the existing political commitment and the state of vertical and horizontal coordination between public administration bodies. Finally, the economic situation of the government departments responsible for spatial planning was also considered, taking into account the current economic crisis and public budget reductions. We used the information collected from these interviews to draft the discussion section of this paper.

\section{Results and Discussion}

This section presents the spatial planning legislation provisions for evaluation and monitoring of plans and discusses their effectiveness.

Significant differences exist between regional legislation regarding evaluation and monitoring of spatial planning. The detailed provisions and laws can be found in Appendix B of this paper. Table 3 summarises the provisions established by regional legislation that affect evaluation and monitoring of spatial plans.

Table 3. Main provisions established by the legislation in force on evaluation, monitoring, and renewal of spatial plans in Spain.

\begin{tabular}{|c|c|c|}
\hline Provisions & $\begin{array}{l}\text { Number of Times Mentioned } \\
\text { (Maximum of } 15 \text { Regional Laws) }\end{array}$ & Comments \\
\hline Monitoring commission & 7 & Body in charge of monitoring the plan. \\
\hline $\begin{array}{l}\text { Monitoring and } \\
\text { management reports }\end{array}$ & 12 & $\begin{array}{l}\text { Provisions for the monitoring, modification and } \\
\text { review of the plan, but with no detailed reference to } \\
\text { the specific contents of the report. }\end{array}$ \\
\hline $\begin{array}{c}\text { Monitoring and } \\
\text { management indicators }\end{array}$ & 3 & $\begin{array}{l}\text { Evaluation and monitoring indicators are only briefly } \\
\text { mentioned in the regional laws. }\end{array}$ \\
\hline $\begin{array}{l}\text { Public consultation } \\
\text { and participation }\end{array}$ & 15 & $\begin{array}{l}\text { Only in } 6 \text { cases is the issue of public participation } \\
\text { mentioned and only in two cases a public } \\
\text { participation project is mentioned. In the other cases, } \\
\text { a public consultation period of only two months } \\
\text { is mentioned. }\end{array}$ \\
\hline $\begin{array}{l}\text { Provisions for Strategic } \\
\text { Environmental Assessment }\end{array}$ & 15 & $\begin{array}{l}\text { All regional laws must transpose the SEA Directive } \\
(2001 / 42 / C E) \text { and the latest amendments of the laws } \\
\text { do transpose it. }\end{array}$ \\
\hline $\begin{array}{l}\text { Territorial Observatories and/or } \\
\text { Spatial Information Systems }\end{array}$ & 4 & $\begin{array}{l}\text { Only four territorial observatories and/or Spatial } \\
\text { Information Systems are mentioned in regional } \\
\text { spatial planning laws. Evaluation and monitoring } \\
\text { indicators are only briefly mentioned in the laws. } \\
\text { In many cases it is the regional spatial plans that } \\
\text { prescribe their creation. }\end{array}$ \\
\hline
\end{tabular}


Most of these provisions are related to monitoring rather than to evaluation of spatial plans. According to interviewee opinions, evaluation has not been sufficiently promoted due to lack of political will. Interviewees also noted the lack of supporting materials or methodological guidelines that could help to accomplish these complex tasks. These provisions are further examined and discussed in the following sections.

\subsection{Monitoring Commissions, Reports, and Indicators}

Based on regional legislation of spatial planning, there is a common obligation to ensure coordination and cooperation between different public administrations and levels. According to interviewees, administrative coordination and cooperation are fundamental aspects of implementing the evaluation and monitoring procedures in spatial plans and are key to avoiding obsolete spatial plans. This viewpoint is supported by other authors [40]. As seen in Table 3, in seven cases regional legislations create an ad-hoc commission for this purpose. Administrative interviews also enhance spatial planning territorial commissions as crucial in spatial planning decision making. However, they also remark that these territorial commissions are failing to carry on out evaluation and monitoring tasks. Certainly, there is a lack of resources for the evaluation and monitoring of spatial plans since there is not a specific department assigned to work on monitoring, nor is there any external evaluation. Furthermore, when there are specific commissions for these purposes, like in Andalusia, they commonly are subject to the political decisions of the responsible public body [29].

All regional laws mention the need to establish forecasting and monitoring measures for these plans, which generally are reports that must be regularly drafted by the monitoring commissions or the public body responsible for spatial planning. However, these laws do not specify detailed contents of these reports. Only in recent laws are indicator systems mentioned as key instruments to evaluate the plans. However, according to the interviewees, indicators defined in spatial plans are not accompanied by any kind of responsibility or commitment.

Moreover, based on interview answers, in most cases ordinary monitoring reports are not elaborated systematically. Technical interviewees pointed out that in general these reports are only available for administrative staff. In addition, these monitoring procedures have been hit by the economic crisis and budget cuts. These concerns are consistent with findings from previous research that shows that in the case of the UK there is a lack of monitoring capacity at the local level where some planning authorities only have a small number of planners with little experience in comprehensive monitoring work [15]. In Spain, this could also be applied to the regional and subregional levels for spatial planning.

\subsection{Public Consultation}

We have stated that evaluation can be understood as any process to assess the adequacy of the plan, therefore public participation could contribute to evaluation and monitoring procedures. Accordingly, we assume public participation as a potential procedure for evaluation of the spatial plans.

Based on developments in planning theory, public participation is essential in spatial planning. According to regional laws, all spatial plans must be submitted for public consultation at least during their approval and renewal procedures. Currently only six regional spatial planning laws refer to public participation and just two of them include the requirement to draft an exhaustive participation project (the cases of Navarre and the region of Valencia).

Some of the interviewees have pointed out that participation is conceived as a passive process, mainly restricted to public consultations. Due to a lack of public participation tradition, most public administrations still are merely willing to share information.

Nevertheless, some progress has been made in public participation since the origins of spatial planning as a public policy in Spain. According to the interviewees, the latest spatial planning processes are carrying out interesting participation procedures that go beyond the legal requirements. 
For example, Valencian Spatial Strategy (the regional plan) has taken into account a large public participation project.

\subsection{Strategic Environmental Assessment for Spatial Plans}

As Table 3 shows, all spatial planning laws include the requirement for a strategic environmental assessment of spatial plans derived from the European Directive on Strategic Environmental Assessment (SEA) [53].

For a long time, environmental principles have been considered fundamental in spatial policies based on U.S. laws on environmental assessment. Environmental assessment has a stronger tradition than spatial plan evaluation and monitoring although they have many points in common, according to most authors [44].

In Spain, as a member of the European Union, the assessment of the environmental impact of plans and programmes is related to European Directive 2001/42/CE [53]. The Strategic Environmental Assessment directive was transposed to the Spanish legal system through Law 9/2006 [54]. The latest legal update at the national level, Law 21/2013 [55] on environmental assessment, includes changes that simplify the administrative procedure. It clearly draws a distinction between the strategic environmental assessment of projects and the strategic environmental assessment of plans and programmes, such as spatial plans. More specifically, two different procedures were established for plans: The Strategic Environmental Declaration for the regular procedure and the Strategic Environmental Report for the simplified procedure (Table 4).

Table 4. Strategic environmental assessment procedures according to Law 21/2013.

\begin{tabular}{cll}
\hline Procedure & \multicolumn{1}{c}{$\begin{array}{c}\text { Document Submitted by the } \\
\text { Project Manager }\end{array}$} & \multicolumn{1}{c}{ Administrative Resolution } \\
\hline STRATEGIC ENVIRONMENTAL & $\begin{array}{l}\text { Initial Strategic Document along } \\
\text { with the Draft Plan }\end{array}$ & $\begin{array}{l}\text { Scope statement, along with a public } \\
\text { consultation period }\end{array}$ \\
\cline { 2 - 3 } $\begin{array}{c}\text { ASSESSMENT (regular procedure) } \\
\text { Title II, Chapter 1, Section 1 }\end{array}$ & $\begin{array}{l}\text { Strategic Environmental Study } \\
\text { along with public participation }\end{array}$ & $\begin{array}{l}\text { Strategic Environmental Report along with a } \\
\text { public consultation period, once the required } \\
\text { environmental report has been approved }\end{array}$ \\
\hline $\begin{array}{c}\text { STRATEGIC ENVIRONMENTAL } \\
\text { ASSESSMENT (simplified procedure) } \\
\text { Title II, Chapter 1, Section 2 }\end{array}$ & $\begin{array}{l}\text { Initial Strategic Document along } \\
\text { with the Draft Plan }\end{array}$ & $\begin{array}{l}\text { Strategic Environmental Report along with a } \\
\text { period of public consultation }\end{array}$ \\
\hline
\end{tabular}

Source: Own preparation based on Law 21/2013 (9 December 2013) on environmental assessment [55].

Both procedures-the Strategic Environmental Declaration and the Strategic Environmental Report-consist of a mandatory and legally binding report issued by the responsible environmental administrative body, which is only valid for two years. In this time period the plan or programme must obtain definitive approval. The new regular procedure for strategic environmental assessment of plans and programmes has a maximum duration of 24 months. The simplified strategic environmental assessment procedure establishes the requirement for the project manager to submit a Strategic Environmental Document along with the initial draft project or plan. In this case, the environmental government body has a maximum of four months, alongside a period of 45 days of public consultation - or six months to issue a favourable opinion or decide that the application must follow the ordinary administrative procedure.

The contents of the Strategic Environmental Study and of the Strategic Environmental Report according to the simplified procedure are detailed in Appendix C. Among other aspects, they include an environmental surveillance programme, in which measures for the environmental evaluation and monitoring of the plans are defined. Law 21/2013 [55] confers the duty to monitor the environmental effects of the plans both to the authorities responsible for the authorization of the plans and the environmental government bodies in charge of performing the environmental impact assessment. 
After all, regional legislation must now be adapted to these new procedures in order to implement the corresponding measures for the different spatial plans.

Many of the experts that we interviewed were surprised to learn that these procedures are relatively new and that the continuous monitoring reporting does not exist in most cases. Moreover, in the majority of cases, these environmental procedures are not linked with monitoring and evaluation of spatial plans. However, in the Valencian case, the new regional legislation-the spatial planning law of 2014-proposes to link both procedures.

\subsection{Territorial Observatories}

Finally, the last provisions identified in legislation are the territorial observatories. They are recognized institutions that serve to provide territorial evidence for the evaluation and monitoring of spatial development. Only four regional spatial planning laws set forth territorial observatories and/or Spatial Information Systems.

Figure 2 shows the territorial observatories identified in regional spatial laws and spatial plans in Spain. Table 5 also names the territorial information systems and the spatial data infrastructures derived from the implementation of INSPIRE Directive 2007/2/CE [56] and Spatial Data Infrastructures (SDI). In addition, some non-statutory observatories have been identified since they provide territorial evidence useful for the evaluation purposes.

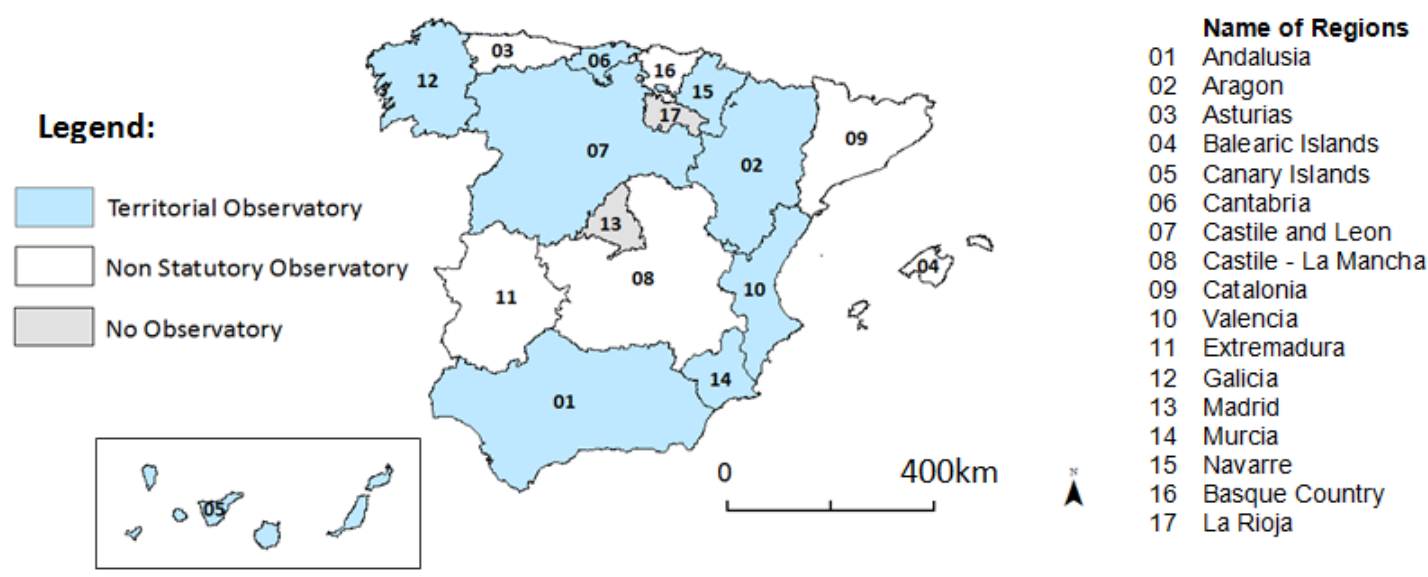

Figure 2. Territorial Observatories according to Spanish regional spatial planning legislation. (Source: own elaboration based on Spanish regional spatial planning legislation).

According to the information gathered, nine regions refer to Territorial Observatories or other alternative statutory territorial institutions providing information for monitoring and evaluation of spatial plans (Figure 2 and Table 5). In many cases, the other alternative official institutions are sectoral observatories or institutions directly related to geographic information services, acting as a regional node of the Spanish Spatial Data Infrastructure network, or established by the INSPIRE Directive. There are other regional spatial data infrastructures, observatories, and institutions not related with spatial planning normative provisions. These non-statutory territorial observatories, such as Landscape Observatory of Catalonia, are also supporting the collection and analysis of regional spatial planning information. In addition, observatories directly linked to Spanish National Observatory of Sustainability (OSE) (Spanish National Observatory of Sustainability (OSE) was created at the beginning of this century through an independent initiative and revived in 2014) have been recognized as non-statutory but useful institutions to gather territorial information [57]. 
Table 5. Territorial observatories related to spatial plans in Spain.

\begin{tabular}{|c|c|c|}
\hline Region & $\begin{array}{c}\text { Regional Spatial } \\
\text { Planning Law (Year) }\end{array}$ & Territorial Observatory \\
\hline Andalusia & 1994 & $\begin{array}{l}\text { - Territorial Observatory of Andalusia } \\
\text { - Spatial Information System for Andalusia (SDI) }\end{array}$ \\
\hline Aragon & 2009 & $\begin{array}{l}\text { - Spatial Information Documentation Centre } \\
\text { - Spatial Information System for Aragon (SDI) }\end{array}$ \\
\hline Asturias & 2004 & * Sustainability Observatory of Asturias (OSE) \\
\hline Balearic Islands & 2000 & * Spatial Development and Sustainability Observatory (OSE) \\
\hline Canary Islands & 2000 & $\begin{array}{l}\text { - Permanent Sustainable Development Observatory } \\
\text { - Observatory on Telecommunications and Information Society }\end{array}$ \\
\hline Cantabria & 2001 & ${ }^{*}$ Geographical Information System for Cantabria (SDI) \\
\hline Castile and Leon & 1998 & * Spatial Information System of Castile Leon (SDI) \\
\hline Castile-La Mancha & 2010 & ${ }^{*}$ Information System of Castile La Mancha (SDI) \\
\hline Catalonia & 1983 & ${ }^{*}$ Landscape Observatory of Catalonia \\
\hline Valencia & 2004 & $\begin{array}{l}\text { - Landscape and Spatial Studies Institute } \\
\text { - Spatial Information System (SDI) }\end{array}$ \\
\hline Extremadura & 2002 & ${ }^{*}$ Territorial Observatory Centre for the Alentejo Extremadura (SDI) \\
\hline Galicia & 1995 & $\begin{array}{l}\text { - Spatial Studies Institute (law amended in 2007) } \\
\text { - Spatial Information System for Galicia (SDI) }\end{array}$ \\
\hline Madrid & 1995 & \\
\hline Murcia & 2005 & $\begin{array}{l}\text { - Spatial Reference System } \\
\text { * Sustainability Observatory for the Murcia region (OSE) }\end{array}$ \\
\hline Navarre & 2002 & $\begin{array}{l}\text { - Territorial Observatory of Navarre } \\
\text { - Spatial Information System of Navarre (SDI) }\end{array}$ \\
\hline Basque Country & 1990 & ${ }^{*}$ Spatial Information System of the Basque Country (SDI) \\
\hline La Rioja & 2006 & \\
\hline
\end{tabular}

The best example is from the case of Navarre. The Territorial Observatory of Navarre is integrated within a technical support unit of the Social Council for Spatial Planning of the Region of Navarre, set up by the regional spatial planning law (Law 35/2002) [58]. Along with political representatives and appointees, more than half of its members are social and economic stakeholders as well as relevant professionals and experts. Therefore, the observatory is a key element for the evaluation and monitoring of Navarre spatial plans [59].

However, in most cases there has been no decisive support for these measures, evidenced by the lack of operational territorial observatories including, for example, the non-functional Territorial Observatory in Andalusia. Furthermore, Spanish territorial observatories are usually indication-focused, i.e., identifying and making geographical information available rather than focusing on prospective studies and evaluation. Many observatories do not go beyond collecting statistical data or serving as a link to information sources or previously defined indicators, rather than proposing their own indicators to assess policies with spatial impacts [60].

\section{Conclusions}

It is important to note that in Spain the spatial planning role has belonged to regional governments for more than thirty years now. Nevertheless, the results presented in this paper show that spatial planning still has important practical problems, especially with respect to evaluation and monitoring tasks. According to the administrative and technical subject experts we interviewed, administrative 
staff reductions due to the economic crisis particularly exacerbate the vulnerability of effective spatial planning implementation.

Although enabling legislation and spatial plans themselves refer to monitoring and evaluation provisions, there is currently a lack of evaluation of spatial plans. In most cases, the monitoring and reporting procedures are only of limited use in practice.

Because many of the Spanish regional spatial planning laws are out-dated, they do not include thorough evaluation and monitoring content for spatial plans, such as monitoring report elements, indicators, public participation procedures, etc. These laws need to be updated to reflect current scholarship and progress in spatial planning frameworks. Right now, with few exceptions, evaluation procedures are not being fully implemented in Spanish spatial plans. Monitoring provision laws, such as the territorial observatories, are ineffective since their implementation is thwarted due to a lack of resources and political will. The same applies to the need for monitoring and evaluation guidelines that could help to enhance this practice.

The results of this paper indicate that evaluation and monitoring tasks carried out in accordance with environmental legislation have had some success. Strategic environmental assessment procedure implies the need to include minimum required content in the spatial plans supported by current spatial planning theory, including the formal requirement for an environmental surveillance programme and a comprehensive and meaningful public participation programme. However, efforts still need to be made because plan reviews are the only actual functional procedures for spatial plan adaptation.

As regards the territorial observatories, to take advantage of their great potential, a few aspects still need to be improved to make progress towards developing prospective studies for spatial planning and evaluating spatial plan objectives. Only after that will territorial observatories effectively support spatial planning decision making.

Moreover, we offer a suggestion that public administrations create a specific body to guarantee the monitoring of spatial plans. This designated body would implement both horizontal and vertical cooperation and coordination between the different territorial stakeholders involved in the spatial planning evaluation and monitoring procedures.

The main obstacles to these participatory processes in Spain come primarily from the lack of experience in this field and the low social awareness of spatial planning issues. The results of our analysis suggest that administrative bodies must work harder to involve the general public in spatial decision making. In particular, the evaluation of spatial plans should involve robust public participation in order to make the whole spatial planning decision-making process more transparent and democratic.

Finally, all of these monitoring and evaluation procedures for spatial plans have been hit severely by economic crisis and public budget cuts. In response, these procedures must be economically and politically reinforced in order to address spatial planning implementation challenges.

Acknowledgments: This material is based on work supported by the Spanish Ministry of Economy, Industry and Competitiveness (MIMECO) under grant GOBEFTER, Ref. CS02012-36960, GOBEFTER II, Ref. CSO2016-78169-R and SWAN -Sustainable Water Action Project (FP 7 Grant Agreement: INCO-20011-7.6). The authors acknowledge the contribution to this work by the project's colleagues and the experts interviewed. Any opinion, finding, conclusion, or recommendation expressed in this paper are those of the authors and do not necessarily express the views of sponsors. We express our gratitude to the editor and the four reviewers for thoughtful comments that improved the quality of this paper.

Author Contributions: Both authors wrote, discussed, and approved the final version of this paper. Sergio Segura collected the data.

Conflicts of Interest: The authors declare no conflict of interest. 


\section{Appendix A}

Table A1. Qualitative interviews: basic structured questionnaire.

\begin{tabular}{|c|}
\hline Qualitative Interviews: Basic Structured Questionnaire \\
\hline Were the periodical monitoring reports drafted, as established by the spatial plans basic management mechanisms? \\
\hline How do the spatial planning commissions operate? \\
\hline How are the information systems and the territorial observatories aimed at evaluating spatial planning, operating? \\
\hline $\begin{array}{l}\text { Do you have indicators or other formal/informal mechanisms in place to evaluate the plans' objectives in practice, as } \\
\text { required by law? }\end{array}$ \\
\hline Do the mechanisms or indicators defined in spatial plans involve any kind of responsibility or commitment? By whom? \\
\hline $\begin{array}{l}\text { How useful is, in practical terms, the strategic environmental evaluation and monitoring mechanism, established by law } \\
\text { in all spatial plans (Directive } 2001 / 42 / C E \text { )? }\end{array}$ \\
\hline $\begin{array}{l}\text { Do public participation projects exist for the evaluation, monitoring, and management of plans? What procedure is used } \\
\text { or envisaged? }\end{array}$ \\
\hline What mechanisms are used for inter-administrative coordination and cooperation on this matter? How do they operate? \\
\hline $\begin{array}{l}\text { How did the economic crisis affect this? Do budget cuts negatively affect evaluation, monitoring and management of } \\
\text { spatial plans? }\end{array}$ \\
\hline $\begin{array}{l}\text { Have other mechanisms for the evaluation, monitoring and management of spatial plans been envisaged? What } \\
\text { improvements can be made in this field? }\end{array}$ \\
\hline siderations or references that the interviewee would like to $c$ \\
\hline
\end{tabular}




\section{Appendix B}

Table A2. Provisions made in Spanish regional spatial planning laws for coordination, cooperation, public participation, evaluation, monitoring, and review of spatial plans.

\begin{tabular}{|c|c|c|c|}
\hline Region & $\begin{array}{c}\text { Spatial Planning Laws (Latest Modification or } \\
\text { Amended Versions) }\end{array}$ & Year (Law still Currently in Force) & Provisions for Evaluation, Monitoring, and Review of Spatial Plans \\
\hline Andalusia & $\begin{array}{l}\text { - Law 1/1994 on Spatial Planning in Andalusia } \\
(11 / 01 / 1994) . \text { (Amended in 2016) }\end{array}$ & $\begin{array}{c}1994 \\
\text { BOJA * 22-1-1994 }\end{array}$ & $\begin{array}{l}\text { - Criteria for the timeline and drafting of the management report (Art. 7) } \\
\text { - Provisions for monitoring and implementation (Art. 7,11 and 43) } \\
\text { - District commissions for drafting and monitoring (Art. } 8 \text { y 13) } \\
\text { - Public consultation (2 months) (Art. 8,13 and 44) } \\
\text { - Spatial Information System (Art. 33) }\end{array}$ \\
\hline Aragon & $\begin{array}{l}\text { - Regional Decree } 2 / 2015 \text { approving the } \\
\text { consolidated text of the Law on Spatial Planning in } \\
\text { Aragon }(17 / 11 / 2015) \text {. (Amended in 2017) }\end{array}$ & $\begin{array}{c}2015 \\
\mathrm{BOA} * 20-11-2015\end{array}$ & $\begin{array}{l}\text { - Spatial management instruments (Art. 5) } \\
\text { - Evaluation and monitoring indicators and indexes (Art. 18) } \\
\text { - Public consultation (2 months) (Art. 19) } \\
\text { - Environmental evaluation and monitoring procedures (Art.19) } \\
\text { - Provisions for modification and review instruments (Art. 20) } \\
\text { - Spatial information systems (Art. 55) } \\
\text { - Spatial indicators system for evaluation and monitoring (Art. 56) } \\
\text { - Spatial Data Infrastructure (Art. 57) }\end{array}$ \\
\hline Asturia & $\begin{array}{l}\text { - Regional Decree } 1 / 2004 \text { approving the } \\
\text { consolidated text of the legal provisions on spatial } \\
\text { and urban planning }(22 / 04 / 2004) \text {. } \\
\text { (Amended in 2010) }\end{array}$ & $\begin{array}{c}2004 \\
\text { BOPA *27-4-2004 }\end{array}$ & $\begin{array}{l}\text { - Public consultation (Art. 7) } \\
\text { - Principles of inter-administrative cooperation and coordination } \\
\text { (Art. 14-16) } \\
\text { - Provisions for regional and sub-regional guidelines (Art. 31) }\end{array}$ \\
\hline Balearic Islands & $\begin{array}{l}\text { - Law 14/2000 on Spatial Planning ( } 21 / 12 / 2000) \text {. } \\
\text { (Amended in 2012) }\end{array}$ & $\begin{array}{c}2000 \\
\text { BOIB * } 27-12-2000\end{array}$ & $\begin{array}{l}\text { - Spatial Policy Coordination Commission (Art. 4) } \\
\text { - Public consultation ( } 2 \text { months) (Art. } 7 \text { and 10) } \\
\text { - Provisions for modification and review instruments (Art. } 7 \text { and 10) }\end{array}$ \\
\hline Canary Islands & $\begin{array}{l}\text { - Regional Decree } 1 / 2000 \text { approving the } \\
\text { consolidated texts of the Spatial Planning Law and } \\
\text { the Natural Sites Law of the Canary Islands } \\
(08 / 05 / 2017) \text {. (Amended in 2015) }\end{array}$ & $\begin{array}{c}2000 \\
\mathrm{BOC}^{*} 15-5-2000\end{array}$ & $\begin{array}{l}\text { - Public and citizen participation principles (Art. } 4 \text { and } 8 \text { ) } \\
\text { - General principles and the duty of administrative cooperation } \\
\text { (Art. } 4 \text { and 10) } \\
\text { - Strategic environmental assessment (Art. 16) } \\
\text { - Public consultation (2 to } 4 \text { months) (Art. 20) } \\
\text { - Provisions for modification and review instruments (Art. 20) }\end{array}$ \\
\hline Cantabria & $\begin{array}{l}\text { - Regional Law 2/2001 on Spatial Planning and } \\
\text { Urban Land Classification systems in Cantabria } \\
(25 / 06 / 2001) \text {. (Amended in 2016) }\end{array}$ & $\begin{array}{c}2001 \\
\mathrm{BOC}^{*} 4-7-2001\end{array}$ & $\begin{array}{l}\text { - Duty of inter-administrative collaboration (Art. 8) } \\
\text { - Carrying capacity (Art. 12) } \\
\text { - Definition of information systems (Art. 12) } \\
\text { - Provisions for modification and review instruments (Art. } 15 \text { and 16) } \\
\text { - Public consultation (Art. 16) }\end{array}$ \\
\hline $\begin{array}{l}\text { Castile La } \\
\text { Mancha }\end{array}$ & $\begin{array}{l}\text { - Regional Decree } 1 / 2010 \text { approving the } \\
\text { consolidated text of the Spatial Planning and Urban } \\
\text { Development }(18 / 05 / 2010) \text {. (Amended in 2016) }\end{array}$ & $\begin{array}{c}2010 \\
\mathrm{DOCM}^{*} 21-5-2010\end{array}$ & - Duty of inter-administrative coordination (Art. 10 and 11) \\
\hline
\end{tabular}


Table A2. Cont.

\begin{tabular}{|c|c|c|c|}
\hline Region & $\begin{array}{c}\text { Spatial Planning Laws (Latest Modification or } \\
\text { Amended Versions) }\end{array}$ & Year (Law still Currently in Force) & Provisions for Evaluation, Monitoring, and Review of Spatial Plans \\
\hline Castile and Leon & $\begin{array}{l}\text { - Law 10/1998 on Spatial Planning in the Castile } \\
\text { Leon region }(05 / 12 / 1998) . \text { (Amended in 2014) }\end{array}$ & $\begin{array}{c}1998 \\
\text { BOCyL * 10-12-1998 }\end{array}$ & $\begin{array}{l}\text { - Social participation (Art. 4) } \\
\text { - Environmental report (Art. 11, amended in 2010) } \\
\text { - Public consultation (45 days) (Art. } 12 \text { and 18) } \\
\text { - Monitoring, review, modification (Art. } 13 \text { and 19) } \\
\text { - Strategic environmental assessment (Art. 17) }\end{array}$ \\
\hline Catalonia & $\begin{array}{l}\text { - Law 23/1983 on spatial policies in Catalonia } \\
(21 / 11 / 1983) \text {. (Amended in 2010) }\end{array}$ & $\begin{array}{c}1983 \\
\text { DOGC *30-11-1983 }\end{array}$ & $\begin{array}{l}\text { - Spatial Policy Coordination Commission (Art. 8), current Spatial Policy } \\
\text { and Urban Development Commission (amended in 2012) } \\
\text { - Provisions for modification and review (Art. 15) }\end{array}$ \\
\hline Extremadura & $\begin{array}{l}\text { - Law 15/2001 on Land and Spatial Planning in } \\
\text { Extremadura (14/12/2001). (Amended in 2015) }\end{array}$ & $\begin{array}{c}2002 \\
\mathrm{DOE} * 3-1-2002\end{array}$ & $\begin{array}{l}\text { - Inter-administrative collaboration (Art. 3) } \\
\text { - Public participation (Art. 7) } \\
\text { - Environmental assessment (amended in 2015) }\end{array}$ \\
\hline Galicia & $\begin{array}{l}\text { - Law 10/1995) on Spatial Planning in Galicia } \\
(23 / 11 / 1995 . \text { (Amended in 2016)- Law 6/2007 on } \\
\text { urgent measures in the field of Spatial Planning and } \\
\text { Coastal Management in Galicia (11/05/2007). } \\
\text { (Amended in 2016) }\end{array}$ & $\begin{array}{c}2007 \\
\text { DOG * } 16-05-2007\end{array}$ & $\begin{array}{l}\text { - Public Hearing and consultation (2 months) (Art. } 10 \text { and 15) } \\
\text { - Annual control report (Art. 11) } \\
\text { - Coordinated Action Plans (Art. 18) } \\
\text { - Environmental assessment (Law 6/2007) } \\
\text { - Spatial Studies Institute (Art. 31) (Law 6/2007, approved in 2011) }\end{array}$ \\
\hline Madrid & $\begin{array}{l}\text { - Law } 9 / 1995 \text { on measures for land, urban and } \\
\text { spatial planning in the region of Madrid } \\
\text { (28/03/1995). (Amended in 2014) }\end{array}$ & $\begin{array}{c}1995 \\
\text { BOCM * 11-04-1995 }\end{array}$ & $\begin{array}{l}\text { - Administrative consultation (Art. 6) } \\
\text { - Commission for Spatial Concerted Action (Art. 7, derogated in 2010) } \\
\text { - Public consultation ( } 2 \text { months) (Art. 18) } \\
\text { - Provisions for modification and review (Art. 18) }\end{array}$ \\
\hline Murcia & $\begin{array}{l}\text { - Law } 13 / 2015 \text { on spatial and urban planning in the } \\
\text { region of Murcia }(30 / 03 / 2015) \text {. }\end{array}$ & $\begin{array}{c}2015 \\
\text { BORM * 6-4-2015 }^{2}\end{array}$ & $\begin{array}{l}\text { - Annual monitoring report on urban development (Art. 11) } \\
\text { - Public participation (Art. 12) } \\
\text { - Spatial Policy Coordination Commission (Art. 15) } \\
\text { - Administrative coordination (Art. 18) } \\
\text { - Spatial Reference System (Art. 21 and 37-39) } \\
\text { - Environmental Assessment (Art. 24, 26 y 69) } \\
\text { - Public consultation (2 months) (Art. 70) } \\
\text { - Review, adaptation and modification (Art. 171-174) }\end{array}$ \\
\hline Navarre & $\begin{array}{l}\text { - Regional Law 35/2002 on Spatial and Urban } \\
\text { Planning in Navarre }(20 / 12 / 2002) \text {. } \\
\text { (Amended in 2015) }\end{array}$ & $\begin{array}{c}2002 \\
\mathrm{BON}^{*} 27-12-2002\end{array}$ & $\begin{array}{l}\text { - Public participation plan (20 days) (Art. 7) } \\
\text { - Spatial Planning Commission (Art. 14) } \\
\text { - Spatial Policy Social Council (Art. 15) } \\
\text { - Inter-administrative coordination and cooperation (Art. 17-19) } \\
\text { - Environmental Assessment (Art. 30) } \\
\text { - Provisions for compliance: spatial monitoring indicators (Art. 32) } \\
\text { - Review, modification and updating (Art. } 35 \text { y 37) }\end{array}$ \\
\hline
\end{tabular}


Table A2. Cont.

\begin{tabular}{|c|c|c|c|}
\hline Region & $\begin{array}{l}\text { Spatial Planning Laws (Latest Modification or } \\
\text { Amended Versions) }\end{array}$ & Year (Law still Currently in Force) & Provisions for Evaluation, Monitoring, and Review of Spatial Plans \\
\hline Basque Country & $\begin{array}{l}\text { - Law } 4 / 1990 \text { on Spatial Planning in the Basque } \\
\text { Country }(31 / 05 / 1990) \text {. (Amended in 2003) }\end{array}$ & $\begin{array}{c}1990 \\
\mathrm{BOPV}^{*} 3-7-1990\end{array}$ & $\begin{array}{l}\text { - Ensures permanent adaptation of spatial planning instruments (Art. 6) } \\
\text { - Public Hearing and consultation ( } 2 \text { months) (Art. } 10 \text { y 13) } \\
\text { - Provisions for modification and review of instruments (Art. 10) } \\
\text { - Coordination body: Spatial Planning Commission for the Basque } \\
\text { Country (Art. 28) } \\
\text { - Participation bodies. Spatial Policy Advisory Council for the Basque } \\
\text { Country (Art. 30) }\end{array}$ \\
\hline Rioja & $\begin{array}{l}\text { - Law 5/2006 on Spatial and Urban Planning in La } \\
\text { Rioja region }(02 / 05 / 2006) . \text { (Amended in 2015) }\end{array}$ & $\begin{array}{c}2006 \\
\mathrm{BOR}^{*} 4-5-2006\end{array}$ & $\begin{array}{l}\text { - Inter-administrative coordination (Art. 8) } \\
\text { - Public participation (Art. 10) } \\
\text { - Provisions for compliance: spatial monitoring indicators (3 months) } \\
\text { (Art. 20) } \\
\text { - Environmental assessment (Art. 20) } \\
\text { - Monitoring reports (every } 5 \text { years) (Art. 21) } \\
\text { - Provisions for the modification and review of instruments (Art. 21) }\end{array}$ \\
\hline Valencia & $\begin{array}{l}\text { - Law } 5 / 2014 \text { on Spatial, Urban and Landscape } \\
\text { Planning in the Valencia region }(25 / 07 / 2014) \text {. } \\
\text { (Amended in 2017) }\end{array}$ & $\begin{array}{c}2014 \\
\mathrm{DOCV}^{*} 31-7-2014\end{array}$ & $\begin{array}{l}\text { - Cooperation and coordination: spatial governance schemes } \\
\text { (Art. } 15 \text { and 16) } \\
\text { - Strategies and actions to achieve the objectives (Art. 16) } \\
\text { - Joint environmental and strategic spatial assessment (Art. 16, 47-56) } \\
\text { - Public participation (Art. 53) } \\
\text { - Provisions for modification and review of instruments (Art. 56) }\end{array}$ \\
\hline
\end{tabular}

* Regional Official Journals: BOJA: Boletín Oficial Junta de Andalucía; BOA: Boletín Oficial Aragon; BOPA: Boletín Oficial Principado de Asturias; BOIB: Boletín Oficial Islas Baleares; BOC: Boletín Oficial Cantabria; BOC: Boletín Oficial Canarias; DOCM: Diario Oficial de Castilla La Mancha; BOCyL: Boletín Oficial Castilla León; DOGC: Diario Oficial Generalitat Catalana; DOE: Diario Oficial Extremadura; DOG: Diario Oficial Galicia; BOCM: Boletín Oficial Comunidad de Madrid; BORM: Boletín Oficial Región de Murcia; BON: Boletín Oficial Navarra; BOPV: Boletín Oficial País Vasco; BOR: Boletín Oficial La Rioja; DOCV: Diario Oficial Comunidad Valenciana. Source: Own preparation based on the Spanish regional legislation on spatial planning. 


\section{Appendix C}

Table A3. Minimum contents of the document, strategic assessment study and report under Law $21 / 2013$ on environmental assessment.

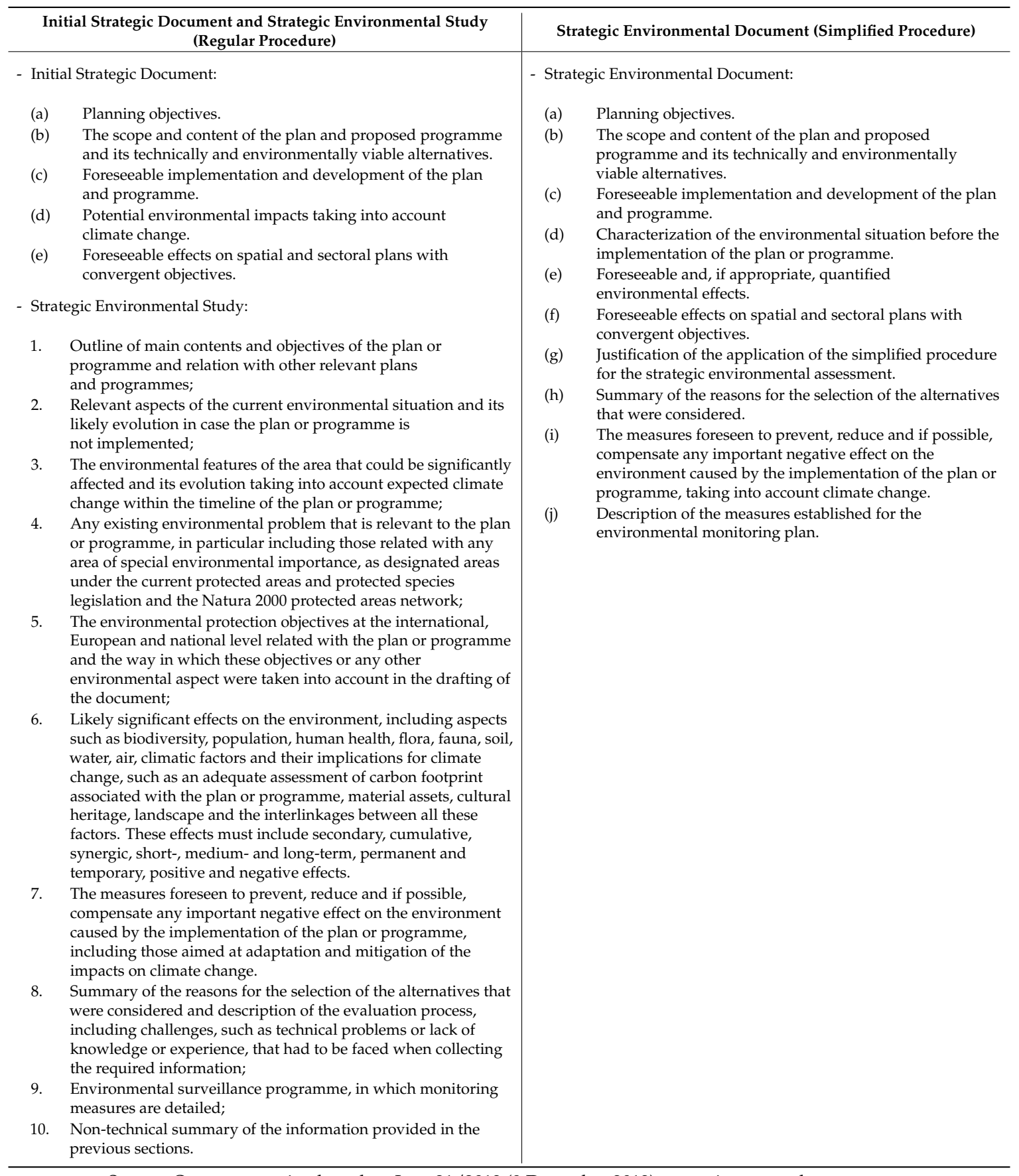

Source: Own preparation based on Law 21/2013 (9 December 2013) on environmental assessment.

\section{References}

1. Council of Europe. European Regional/Spatial Planning Charter. In Proceedings of the European Conference of Ministers responsible for Regional Planning (CEMAT), Torremolinos, Spain, 20 May 1983.

2. Hildenbrand Scheid, A. Política de Ordenación del Territorio en Europa; Universidad de Sevilla: Seville, Spain, 1996; ISBN 978-84-472-0315-4. 
3. Nilsson, K.L.; Rydén, L. 18. Spatial Planning and Management. In Rural Development and Land Use; Rydén, L., Karlsson, I., Eds.; Baltic University Press: Uppsala, Sweden, 2012; pp. 205-227; ISBN 978-91-86189-11-2.

4. Commission of the European Communities. Green Paper on Territorial Cohesion: Turning Territorial Diversity into Strength; CEC: Brussels, Belgium, 2008.

5. Nuissl, H.; Heinrichs, D. Fresh Wind or Hot Air-Does the Governance Discourse Have Something to Offer to Spatial Planning? J. Plan. Educ. Res. 2011, 31, 47-59. [CrossRef]

6. Faludi, A. Cohesion, Coherence, Co-Operation: European Spatial Planning Coming of Age? Routledge: Abingdon, Oxon, UK; New York, NY, USA, 2010.

7. Faludi, A. Centenary paper: European spatial planning: Past, present and future. Town Plan. Rev. 2010, 81, 1-22. [CrossRef]

8. Faludi, A. Multi-Level (Territorial) Governance: Three Criticisms. Plan. Theory Pract. 2012, 13, $197-211$. [CrossRef]

9. López Trigal, L. Diccionario de Geografía Aplicada y Profesional: Terminología de Análisis, Planificación y Gestión del Territorio; Universidad de León: Leon, Spain, 2015.

10. Cullingworth, B.J.; Caves, R. Planning in the USA: Policies, Issues, and Processes, 2013th ed.; Routledge: London, UK; New York, NY, USA, 1997.

11. Gómez Orea, D. Ordenación Territorial, 3rd ed.; Mundi-Prensa: Madrid, Spain, 2013.

12. Centre for Urban Policy Studies, University of Manchester; Department of Town and Regional Planning, University of Sheffield. Measuring the Outcomes of Spatial Planning in England. Final Report; Royal Town Planning Institute: Stowmarket, UK, 2008.

13. Ponzini, D. Introduction: Crisis and renewal of contemporary urban planning. Eur. Plan. Stud. 2016, 24, 1237-1245. [CrossRef]

14. Waterhout, B.; Othengrafen, F.; Sykes, O.J. Neo-liberalization Processes and Spatial Planning in France, Germany, and the Netherlands: An Exploration. Plan. Pract. Res. 2013, 28, 141-159. [CrossRef]

15. Wong, C.; Baker, M.; Kidd, S. Monitoring Spatial Strategies: The Case of Local Development Documents in England. Environ. Plan. C Politics Space 2006, 24, 533-552. [CrossRef]

16. Petrov, L.O.; Shahumyan, H.; Williams, B.; Convery, S. Scenarios and Indicators Supporting Urban Regional Planning. Procedia Soc. Behav. Sci. 2011, 21, 243-252.

17. Marques Da Costa, E. Monitoring and evaluation of policies: Methodological contribution based on the Portugal case study. In De la Evaluación Ambiental Estratégica a la Evaluación de Impacto Territorial: Reflexiones Acerca de la Tarea de Evaluación = (From Strategic Environmental Assessment to Territorial Impact Assessment: Reflections about Evaluation Practice); Farinós i Dasí, J., Ed.; Universidad de Valencia: Valencia, Spain, 2011; pp. 309-330.

18. Stead, D.; Nadin, V. Shifts in territorial governance and the Europeanization of spatial planning in Central and Eastern Europe. In Territorial Development, Cohesion and Spatial Planning: Building on EU Enlargement; Adams, N., Cotella, G., Nunes, R., Eds.; Routledge: Abingdon, Oxon, UK; New York, NY, USA, 2011; pp. 154-177.

19. Hajer, M.A.; Grijzen, J.; Van't Klooster, S.A. Strong Stories: How the Dutch are Reinventing Spatial Planning; Design and Politics; 010 Publishers: Rotterdam, The Netherlands, 2010.

20. Aguilar Villanueva, L.F. La Implementación de las Políticas; Grupo Editorial Miguel Ángel Porrua: Mexico City, Mexico, 1993.

21. Hogwood, B.W.; Gunn, L.A. Policy Analysis for the Real World; Oxford University Press: Oxford, UK, 1984.

22. Farinós i Dasí, J. Desarrollo Territorial y Gobernanza: Refinando significados desde el debate teórico pensando en la práctica. Un intento de aproximación fronética. Desenvolv. Reg. Debate 2015, 5, 4-24.

23. Girardot, J. Inteligencia Territorial y Transición Socio-Ecológica. Rev. Andal. Relac. Lab. 2010, 23, 15-39.

24. National Environmental Policy Act (Public Law 91-190). 1969; 42 U. S. Code, Chapter 55; pp. 4321-4347. Available online: https:/ / www.fsa.usda.gov/Internet/FSA_File/nepa_statute.pdf (accessed on 21 September 2017).

25. UN. System of Social and Demographic Statistics. Draft Guidelines on Social Indicators; United Nations Publications; Statistical Commission: New York, NY, USA, 1974.

26. UN. Indicators of Sustainable Development. Guidelines and Methodologies; United Nations, Economic and Social Affairs: New York, NY, USA, 2007.

27. Benabent Fernández de Córdoba, M. Introducción a la Teoría de la Planificación Territorial; Universidad de Sevilla: Seville, Spain, 2014. 
28. Benabent Fernández de Córdoba, M. La Ordenación del Territorio en España: Evolución del Concepto y de su Práctica en el Siglo XX; Universidad de Sevilla, Junta de Andalucía, Consejería de Obras Públicas y Transportes: Seville, Spain, 2006.

29. Benabent Fernández de Córdoba, M. Los planes de ordenación del territorio en España. De la instrumentación a la gestión. In Agua, Territorio y Paisaje: De los Instrumentos Programados a la Planificación Aplicada: $V$ Congreso Internacional de Ordenación del Territorio = 5th International Congress for Spatial Planning: Málaga 22, 23 y 24 de Noviembre de 2007; Sánchez Pérez-Moneo, L., Troitiño Vinuesa, M.Á., Eds.; Asociación Interprofesional de Ordenación del Territorio (FUNDICOT): Madrid, Spain, 2009; pp. 143-158.

30. Elorrieta Sanz, B. La Planificación Territorial en el Estado Español a la luz de las Políticas Territoriales Europeas. De la Teoría a la Praxis. Ph.D. Thesis, Universitat de Barcelona, Barcelona, Spain, 2013.

31. Farinós i Dasí, J.; Romero González, J.; Salom, J. Cohesión e Inteligencia Territorial: Dinámicas y Procesos Para una Mejor Planificación y Toma de Decisiones; Universidad de Valencia: Valencia, Spain, 2009.

32. Feria Toribio, J.M.; Rubio Tenor, M.; Santiago Ramos, J. Los planes de ordenación del territorio como instrumentos de cooperación. Bol. Asoc. Geógr. Esp. 2005, 39, 87-116.

33. Hildenbrand Scheid, A. La política de ordenación del territorio de las Comunidades Autónomas: Balance crítico y propuestas para la mejora de su eficacia. Rev. Derecho Urban. Medio Ambient. 2006, 40, 79-139.

34. Martín Jiménez, M.I. La Ordenación del Territorio en las Comunidades Autónomas. Desarrollo Normativo. Polígonos. Rev. Geogr. 2014, 26, 321-348. [CrossRef]

35. Nel-lo i Colom, O. Ordenar el Territorio: La Experiencia de Barcelona y Cataluña; Tirant Humanidades: Valencia, Spain, 2012.

36. Serrano Rodríguez, A. Ordenación del territorio en una sociedad española inmersa en el cambio global. Ciudad. Rev. Inst. Univ. Urban. Univ. Valladolid 2012, 15, 21-50.

37. Urkidi Elorrieta, P. Policies of land management in the Basque Autonomous Community, 1990-2006. Bol. Asoc. Geógr. Esp. 2010, 15, 189-212.

38. Zoido Naranjo, F. Ordenación del territorio en Andalucía: Reflexión personal. Cuad. Geogr. Univ. Granada 2010, 47, 189-221.

39. Benabent Fernández de Córdoba, M. Treinta años de ordenación del territorio en el estado de las autonomías. In El Planejament Territorial a Catalunya a Inici del Segle XXI; Castañer, M., Ed.; Institut d'Estudis Catalans, Societat Catalana d'Ordenació del Territori: Barcelona, Spain, 2012; pp. 140-165. ISBN 978-84-9965-121-7.

40. Aldrey Vázquez, J.A.; Rodríguez González, R. Instrumentos de ordenación del territorio en España. In Territorio. Ordenar Para Competir; Rodríguez González, R., Ed.; Netbiblo: Oleiros, La Coruña, Spain, 2010; pp. 183-205.

41. Cuyás Palazón, M. Urbanismo Ambiental y Evaluación Estratégica; S.A. ATELIER LIBROS: Barcelona, Spain, 2007.

42. Gómez Orea, D.; Gómez Villarino, M.; Gómez Villarino, A. Evaluación Ambiental Estratégica: Un Instrumento Para Integrar el Medio Ambiente en la Elaboración de Planes y Programas; Mundi-Prensa: Madrid, Spain, 2006.

43. Cutaia, F. Strategic Environmental Assessment: Integrating Landscape and Urban Planning; Springer: Cham, Switzerland, 2016.

44. Farinós i Dasí, J. De la Evaluación Ambiental Estratégica a la Evaluación de Impacto Territorial: Reflexiones Acerca de la Tarea de Evaluación = (From Strategic Environmental Assessment to Territorial Impact Assessment: Reflections about Evaluation Practice); Universidad de Valencia: Valencia, Spain, 2011.

45. Asociación de Geógrafos Españoles. Manifiesto por Una Nueva Cultura del Territorio 2006. Available online: http://www.geografos.org/images/stories/interes/nuevacultura/manifiesto-por-una-nuevacultura-del-territorio-d5.pdf (accessed on 10 July 2017).

46. Hernández Martínez, E. Por Una Nueva Cultura del Territorio. EL País 2008. Available online: http: / / elpais.com/diario/2008/04/25/andalucia/1209075726_850215.html (accessed on 10 July 2017).

47. Albrechts, L. Ingredients for a More Radical Strategic Spatial Planning. Environ. Plan. B Plan. Des. 2015, 42, 510-525. [CrossRef]

48. Albrechts, L. Reframing strategic spatial planning by using a coproduction perspective. Plan. Theory 2013, 12, 46-63. [CrossRef]

49. Albrechts, L.; Balducci, A. Practicing Strategic Planning: In Search of Critical Features to Explain the Strategic Character of Plans. disP Plan. Rev. 2013, 49, 16-27. [CrossRef]

50. Roodbol-Mekkes, P.H.; Van der Valk, A.; Korthals Altes, W.K. The Netherlands spatial planning doctrine in disarray in the 21st century. Environ. Plan. A 2012, 44, 377-395. [CrossRef] 
51. Sánchez Pérez-Moneo, L.; Troitiño Vinuesa, M.Á. Agua, Territorio y Paisaje: De los Instrumentos Programados a la Planificación Aplicada: $V$ Congreso Internacional de Ordenación del Territorio $=5$ th International Congress for Spatial Planning. Málaga 22, 23 y 24 de Noviembre de 2007; Asociación Interprofesional de Ordenación del Territorio (FUNDICOT): Madrid, Spain, 2009.

52. López Estrada, R.E.; Deslauriers, J.P. La entrevista cualitativa como técnica para la investigación en Trabajo Social. Margen Rev. Trab. Soc. Cienc. Soc. 2011, 61, 2-19.

53. European Parliament and of the Council. Directive 2001/42/EC of the European Parliament and of the Council of 27 June 2001 on the assessment of the effects of certain plans and programmes on the environment. Off. J. Eur. Union 2001, 197, 30-37.

54. Law 9/2006, de 28 de abril, sobre evaluación de los efectos de determinados planes y programas en el medio ambiente (In force until 12 December 2013). Boletín Oficial del Estado 2006, 102, 16820-16830. Available online: https:/ / www.boe.es/boe/dias/2006/04/29/pdfs/A16820-16830.pdf (accessed on 21 September 2017).

55. Law 21/2013, de 9 de diciembre, de evaluación ambiental. Boletín Oficial del Estado 2013, 296, 98151-98227. Available online: https:/ /www.boe.es/boe/dias/2013/12/11/pdfs/BOE-A-2013-12913.pdf (accessed on 21 September 2017).

56. European Parliament and of the Council. Directive 2007/2/EC of the European Parliament and of the Council of 14 March 2007 establishing an Infrastructure for Spatial Information in the European Community (INSPIRE). Off. J. Eur. Union L 2007, 108, 1-14.

57. Spanish National Observatory of Sustainability (OSE, Observatorio de la Sostenibilidad en España). Available online: http:/ / www.observatoriosostenibilidad.com (accessed on 21 September 2017).

58. Law 35/2002, de 20 de diciembre, de Ordenación del Territorio y Urbanismo de Navarra. Boletín Oficial del Estado 13, 1885-1941. Available online: http:/ / www.boe.es/boe/dias/2003/01/15/pdfs/A01885-01941.pdf (accessed on 21 September 2017).

59. García Martínez, M. El proceso de evaluación territorial, algo más que seguimiento. In De la Evaluación Ambiental Estratégica a la Evaluación de Impacto Territorial: Reflexiones Acerca de la Tarea de Evaluación = (From Strategic Environmental Assessment to Territorial Impact Assessment: Reflections about Evaluation Practice); Farinós i Dasí, J., Ed.; Universidad de Valencia: Valencia, Spain, 2011; pp. 331-348.

60. Farinós i Dasí, J. Inteligencia Territorial para la planificación y la gobernanza democráticas: Los observatorios de los territorios. Rev. Proyecc. 2011, 5, 45-69.

(C) 2017 by the authors. Licensee MDPI, Basel, Switzerland. This article is an open access article distributed under the terms and conditions of the Creative Commons Attribution (CC BY) license (http://creativecommons.org/licenses/by/4.0/). 